\title{
Expansion of the Open Area (Johari Window) and Group Work Directed to Enhancing the Level of Subjective Well-being
}

\author{
Devrim Erginsoy Osmanoğlu \\ Correspondence: Devrim Erginsoy Osmanoğlu, Department of Educational Sciences, Faculty of Education, Kafkas \\ University, Turkey.
}

Received: March 11, 2019

Accepted: April 11, 2019 Online Published: April 22, 2019

doi:10.11114/jets.v7i5.4128

URL: https://doi.org/10.11114/jets.v7i5.4128

\begin{abstract}
Open and healthy communication plays an important role in the determination of human relations. While people are interpreting the bodily feedbacks given by the people they are communicating with to understand their intentions, they rely on the information they give about themselves; that is, their explanations about themselves. The Johari Window technique is the technique that supports the creation of trust in interpersonal relations, as well as the elimination of problems arising in the communication used in counseling processes. According to this technique, the area including an individual's behaviors, attitudes, feelings, experiences, skills or clear information about how he/she looks is called the open area. This area's being broad plays an important role in the individual's developing close relationships with other members of society, in his/her happiness or in his/her living positive emotions. In many studies, it was determined that both the physical health and psychological health of the people who shared their knowledge about themselves were positively affected. The purpose of the current study is to expand the open area of the group members participating in nine-session group work by using Johari window so that their understanding and awareness of themselves can be improved and their understanding of others can be enhanced and they can be enabled to see interpersonal differences. The study group of the current research is comprised of 12 students; 5 females and 7 males, from the Department of Psychological Counseling and Guidance who participated in the study on a volunteer basis. In the current study, in order to collect data, the Psychological Well-being Scale, which was developed on the basis of Ryff's (1989) psychological well-being model and the Johari Window Evaluation Form developed according to the model proposed by Joseph Luft and Harry Ingham were used. According to the posttest results obtained at the end of the study, it was observed that the open areas of the university students participating in the group work were expanded and their scores taken from the sub-dimension "positive relationships with others" of the subjective well-being increased.
\end{abstract}

Keywords: Johari window, subjective well-being

\section{Introduction}

The existence of healthy social relations is a psychological need and the happiness of people depends on the extent to which this need is met (Nur Şahin, 2011). Communication plays an important role in the formation of human relations. While people are interpreting the bodily feedbacks given by the people they are communicating with to understand their intentions, they rely on the information they give about themselves; that is, their explanations about themselves. They determine the quality of social support they will offer and the direction of the human relations they will establish on this explanation and trust (K1lıç \& Önen, 2011). The individual's talking about himself/herself during his/his attempts to create new relationships provides the ground for the development of the relationship as it can bring trust, warmth and acceptance (Ataşalar, 1996). In his book "The Transparent Self" (1964), Jourard stated that conversational patterns are related to the level of intimacy between people. In other words, when a person reveals his / her personal information, the interlocutor responds to it. Subsequent studies have determined that this is about the principle of reciprocity in disclosure. According to this principle, as long as the person gives information about himself/herself and shows closeness to the other person, the other person will give the same amount of information and feels close (Burger, 2006; p:466; Ağlamaz, 2006 ). The Johari Window technique is the technique that supports the creation of trust in interpersonal relations, as well as the elimination of problems arising in the communication used in counseling processes. There are two dimensions involved in this technique; what the person knows about himself/herself and what other people have learned about this person (Yıldız, 2014). From the interaction of these two dimensions, four states emerge: 
1. General State (Open Area): This refers to open information about the individual's behaviours, attitudes, emotions, experiences, skills and how he/she looks. This area is generally easily observable by both the person and the group and includes the information the individual is not hesitant about disclosing.

2. Special State (Hidden Area): This hidden or avoided self includes the information that a person knows about himself/herself but consciously wants to hide. Information about one's concerns, fears, feelings of jealousy is kept in this area. Reduction of hidden area opens the way to effective and trusting communication.

3. Suspicious State (Blind Area): It includes the information that is known by others about the person yet is not known or rejected by the person. The blind area can also be named as the ignorance about oneself. This is an area of increasing self-consciousness. This area of any group member can be narrowed through the sensitive feedbacks given by the other group members and by encouraging the member to be more open.

4. Unknown State (Unknown): It includes the remarkable characteristics of the individual that are not known much by both himself/herself and others. Unknown subjects can be emotions, behaviours, attitudes, abilities or they can be deeper aspects of a personality, and these unrecognized features can affect the individual's behaviours in various ways. Lack of information about the source of behaviours and thoughts can be seen much in individuals who are lacking experience or having low self-efficacy beliefs (Luft \& İngham, 2014; Malhan and Ersoy, 2001).

The Johari Window can be used for the person to understand himself/herself and to raise his/her personal awareness and also to enable him/her to understand others and to see interpersonal differences. Harmony in interpersonal relations and a healthy communication depend on the width of the open area. The main purpose of all work groups should be to expand the open area of the individual member because open or free area can be seen as the area where good communication and cooperation take place. Individuals with a wide open area can communicate well with others in a reciprocal understanding. On the other hand, while the wideness of the "blind area" refers to "blind communication", the wideness of the "hidden area" refers to "crippled communication" (Yıldız, 2014; Nofriza, 2017).

Decrease in the number of people with whom intimate issues such as private life can be talked about may mean that communication established with other people is distant from being intimate and is like doing it as a requirement of a role (Üstündağ, 2006). Spherer and Wheeless, who examined the nature of self-disclosure in developing relationships, concluded that the amount of self-disclosure is significantly effective on the relationship development, whether the relationship lasts long or not, and on the relationship's dimensions of depth, honesty, intent, and positivity (Nur Şahin, 2011). The forms of communication which are influential on the development of close relationships between individuals play an important role in the happiness of the person or his/her living positive emotions. In many studies, it has been determined that both the physical health and psychological health of the people who tend to share information about themselves are positively affected.

In terms of the psychological and physical health of the individual, not only establishing relationship and self-disclosure but also how this relationship is established is important (Doğan and Sapmaz, 2012). The feeling expressed as feeling in the daily life is defined as "subjective well-being" by Diener (1984) in the literature. Subjective well-being represents a positive aspect of mental health (Diener, 2000). It is clear that the subjective well-being of the individual will have many positive reflections in his/her life, such as experiencing positive emotions, becoming productive, coping with or adapting to inevitable negative life experiences, and building more qualified relationships with people. According to Myers and Deiner (1995), besides these two components, there is a third component called life satisfaction (cited in Özen, 2010). In the positive feelings dimension of subjective well-being, there are feelings such as joy, excitement, pride, hope, interest, vigilance and trust while in its negative feelings dimension, there are feelings such as sadness, guilt, hatred, and anger. The third dimension, life satisfaction, includes the individual's sense of satisfaction and evaluations related to different fields of life. In order to be able to claim that the subjective well-being of the individual is high, his/her life satisfaction should be high, positive emotions should be experienced frequently and negative feelings should be experienced less (Eryllmaz, 2010).

Many theories have been created to explain the subjective well-being by placing many different ideas developed to explain what makes the individual happy on a scientific ground. These theories are goal theories, theory of effectiveness, inductive and deductive theories, theories of judgment, adaptation theory, bond theory, equilibrium theory and Ryff's psychological well-being theory. According to goal theories, what makes individuals whose goals and desires are different happy is their behaving in compliance with goals suitable for their own values (Saygin, 2008). According to theory of effectiveness, what brings happiness to the life of individuals is their being engrossed in an activity so deeply that they do not care about anything. Csikszentmihalyi, (2005) calls this state as "flow". Happiness is individuals' feeling satisfied as a result of involvement in an activity and product of their effectiveness (Diener, 2000; Yavuz, 2006). According to inductive theories, happiness is the combination of the satisfaction taken by the individual from different fields of life such as family life, marriage, income level. According to the deductive theorists, the difference between the 
happiness levels of people stems from their tendencies towards thinking positively and negatively. That is, while the inductive theory argues that subjective-well being depends on living conditions, the deductive theory contends that the personality is more influential than living conditions on subjective well-being (Brief, George, Butcher \& Link, 1993). The theories of judgment argue that subjective-well being emerges as a result of the comparison made between some standards such as the state of others, past conditions and desires and actual conditions. That is, the individual decides whether he/she is happy or not by comparing himself/herself with other individuals in many respects. The theory of adaptation argues that the individual creates happiness as a result of the comparison he/she makes between his/her new situation and standards which he/she has had for a long time and which are a part of his/her normal life. If the individual's new situation is better than his/her old standards, then he/she will feel happy but if this new situation continues for a long time then the person will get used to them and they won't make him/her happy anymore; thus, he/she will seek new standards to be happy (Yetim, 2001; Nur şahin, 2011). The theorists advocating the bond theory are of the opinion that the individual's happiness depends on the existence of a rich cognitive network or conditionings. They see the reason for the unhappiness as individuals' being connected to each other with negative bonds and their limited and isolated cognitive networks (Yetim, 2001). The dynamic equilibrium theorists have stated that the level of subjective well-being is associated with inherent personality traits to some extent yet positive or negative deviations from the person's normal life affect his/her level of happiness (Headey and Wearing, 1989). The six factors making up the Ryff's subjective well-being concept are classified as follows;

Self-acceptance: The individual's being in a positive attitude towards himself/herself by accepting himself/herself and his/her past life,

Positive Relationships: The people who can develop positive relationships with people they are living with can develop a sense of deep empathy and love. Establishing open and reliable relationships with other people is an indication of positive mental health and maturity.

Autonomy: It refers to characteristics such as making decisions on the basis of one's own standards as independent of others and being able to resist to social pressure. Autonomy creates the sense of freedom in the daily life of the person.

Environmental Mastery: It is seen to be the skill of coping with the complex events experienced throughout the life and of controlling them. Environmental mastery also defined as the individual's selecting the environment suitable for his/her own spiritual conditions is one of the features of positive mental health.

Purpose in life: The individual's believing that his/her life is meaningful and has a goal.

Personal Growth: Being open to new experiences is an important criterion for the personal growth of the individual and for his/her self-actualization.

Ryff (1989) admits that these six dimensions are affected by the factors such as the culture, history, ethnic origin and class of the individual and all of them together contribute to the happiness of the individual (Ryff, 1989; Ryff , 2014; Özen, 2005).

When all these theories are examined, it is seen that the individual's social relations in his/her daily life, how these relations are organized and his/her level of understanding others are important in terms of the level of subjective well-being. Expanding the open area representing the person in the Johari Window, his/her view of the world and the way others perceive him/her, and narrowing of the unknown area can be achieved by increasing the degree of self-disclosure. Expanding the open area representing how the person in Johari Window sees himself/herself, his/her view of the world and how others perceive the person and reducing the "unknown area" can make it possible to increase the level of individual's disclosure. The purpose of the current study is to expand the "open area" of the group members participating in a 9-session group work in Johari window aiming to enhance the group members' understanding of themselves, raise their self-awareness and enable them to understand others and see interpersonal differences and to improve their subjective well-being levels. In this context, the general objectives of the group work have been constructed as follows:

- Helping them in their relationships with the people involved in their lives and share their positive and negative feelings about these relationships,

- Encouraging them to express the effect of their previous experiences on the approaches they have adopted to life and more importantly their effect on their attitudes deeply rooted in their life attitudes,

- Raising the group members' self awareness,

- Encouraging them to develop different and multi-faceted views for findings solutions to life problems.

In the current study, the following hypotheses were tested: 
1. The experimental group' posttest well-being scores will be significantly higher than their pretest well-being scores.

2. The experimental group's feedback and being open posttest scores making up their open area scores will be significantly higher than their pretest scores.

\section{Method}

The current study was designed according to the experimental method and employed the single-group pretest-posttest research design. The experimental design is a research method aiming to determine cause-effect relationships between events and used to test the hypotheses proposed by the researcher. When the same subjects' measurements for the dependent variable before and after the experimental application are taken, measurements of the subjects need be repeated at different time intervals (Büyüköztürk, 2012).

\subsection{Study Group}

The study group of the current research is comprised of 12 students; 5 females and 7 males, from the Department of Psychological Counseling and Guidance who participated in the study on a volunteer basis. Before the formation of the group, a short interview was made with the students wanting to participate. Care was taken to select the ones not having participated in such a study before.

\subsection{Data Collection Tools and Analysis}

In the current study, in order to collect data, the Psychological Well-being Scale, which was developed on the basis of Ryff's (1989) psychological well-being model and the Johari Window Evaluation Form developed according to the model proposed by Joseph Luft and Harry Ingham were used.

\subsubsection{Psychological Well-Being Scale}

In the scale developed by Ryff in 1989 and adapted to Turkish by Cenkseven in 2004, there are 84 items. The lowest score to be taken from the scale is 84 and the highest score to be taken is 504. The increase in the total score indicates increasing psychological well-being. The scale was developed to measure 6 dimensions of psychological well-being: 1) autonomy-independence, personal determination, 2) environmental mastery, the person's managing his/her life, 3) personal growth - being open to new experiences, 4) positive relationships with others - being satisfied with relations, 5) purpose in life - the person's believing that his/her life is meaningful, 6) self-acceptance - having positive attitudes to the self and his/her past. Each of the 6 factors in the scale has 14 items. The loading of the scale items were found to be ranging from .54 to .76 . In the confirmatory factor analysis, the fit indices were found to be as follows RMSEA $=0.08$, $\mathrm{SRMR}=0.04, \mathrm{GFI}=0.96, \mathrm{NFI}=0.94, \mathrm{RFI}=0.92, \mathrm{CFI}=0.95$ and $\mathrm{IFI}=0.95$. The Cronbach Alpha internal reliability coefficient of the scale was calculated to be .80 . Test-retest has revealed that between the first and second administration of the scale, there is a high level positive and significant correlation $(r=0.86, \mathrm{p}<.001)$.

\subsubsection{Johari Window Evaluation Form}

This evaluation form developed by the psychologist Joseph Luft and psychiatrist Harry Ingham is a technique used to eliminate the problems stemming in communication and to command trust and it is also used in counselling processes. The 48-item Johari Window evaluation form includes items related to giving feedback and being open. While the scale is evaluated, 4 different scores can be obtained that are Gl (Open Area), G2 (Hidden Area), Al (Blind Area) and A2 (Unknown Area). Each item is assigned 1 point. The scores taken from G1 and G2 are summed and then divided into two and in this way their mean is taken and the area known to the self is calculated. The mean of A1 and A2 gives the score of the area not known to the self. The intersection point of these scores gives the size of the open area.

\subsection{Experimental Application Procedure}

Following the pre-test administered during the group work, one session was conducted each week and the whole experimental application lasted for 9 weeks. Each session lasted for 90 minutes. After the completion of the 9-session experimental process, the effect of the application was tested through post-test analyses. The session contents related to group works are given below:

\section{$1^{\text {st }}$ Session: Name Stories}

After a short introduction with the participating group members, the group rules were determined. As the first session is an introduction session, it was initiated by asking the participating students' names and their meanings. Then the session was ended by letting the group members talk about these questions; "Do you think that your name represents you? If you had a chance to select your name, which name would you prefer? From which aspects do you find the name you would select close to you?" and the names they found suitable for the other group members and other people. In this way, it was attempted to help the group members to get to know themselves, to make communication with them easier and help them understand the first impression they leave on others. 


\section{$2^{\text {nd }}$ Session: Drawing of Social Atom}

In this activity, the main emphasis was on getting to know the group members more closely by talking about their family members and their relationships with these members. While this activity was being carried out, crayons and pastel colours were used. The activity was conducted as follows: The group members were asked to draw the people who are having or having had positive or negative impacts on their lives together with the symbols indicating their most typical characteristics and then to interpret these symbols. In this way, information was elicited about their relationships with people who are important in their lives. Then, everybody interpreted their social atoms in turn. Then a whole group discussion was started about why they selected their symbols, why they selected these colours and who these symbols represented. All the group members actively participated in this discussion.

$3^{\text {rd }}$ Session: First Memories

Adler emphasized that people describe their first memories as my life story from a subjective point of view. He also states that the first memories that individuals remember about their childhood have formed their opinions which approve and support their current world views or in Adler's words, formed their conceptual schemes. Moreover, he argues that as they direct the efforts invested by the individual for meaningfulness and security, they constitute the law of behaviours or the goal of a functional life (Kopp and Eckstein, 2004). The first memories contain individuals' different approaches of life and more importantly their effects embedded in their life attitudes. At this point, the first memories are the starting point of a human being and a strong indication of the individual's orientations (Mc.Curdy, 1986). The use of the first memories in the counselling environment helps the individual to understand that he/she has a unique and effective empathy potential, in establishing empathy with the client and in understanding his/her way of perception (Arthur, 2001). In addition, Martin Mayman (1957) believes that the first memories determine the life style of the person and stresses that these memories are chosen and unconsciously organized according to the personality dynamics of the person (cited in Fowler, Hilsenroth and Handler, 2000, Balen, 1999). Mayman (1968) named them as personality myths by thinking that these experiences are mostly related to the pieces of personality, directly reflected on the functioning of the ego and that they define the psychological realities that show the dominant subjects in human life (cited in Ghazala and Manzoor, 2003). For these reasons, the group members were asked to describe their first three memories which they had clearly remembered in the first years of their lives and how they had affected their lives.

$4^{\text {th }}$ Session: Communication Cards

Therapeutic cards reflect the inner world of people as a projective technique. The users of these cards make their own interpretation of what they have seen. Thus, people using the cards can make a special sense about their current state and themselves from what they have seen in the cards. Therapeutic cards can be used for individual, family and group counselling. Through these cards, interpersonal interactions can be established and individuals can explore their inner worlds.

In the study, the therapeutic card groups such as ON; SAGA; HABITAT; PERSONA; MORENA; MYTHOS; 1001 NIGHTS were used to encourage the participants to think about the situations they see as problems negatively affecting their lives and then they were asked to select the cards to represent the past, present and future of these situations. It was aimed to improve the group members' emotional discharge and interpersonal interactions by allowing them to share their feelings about the situations they see as problematic. In the next stage, each participant was made to select a card for the solution to the problem and last card was asked to be chosen as an alternative solution; thus, a total of 5 cards were selected by each participant and in this way the problems were reified and the participants were encouraged to think about solutions. The opinions of the other group members were sought about the solution and alternative solutions and thus each participant was enabled to make use of different viewpoints.

$5^{\text {th }}$ Session: Dreams

Freud widely used dreams in the counseling process. Yet, Freud believes that the banned thoughts, impulses, and desires that are suppressed in subconscious are lived through symbols in dreams. Unlike Freud, Adler sees dreams as the structural and functional processes of the future, which consist entirely of the lifestyle of the client, due to the thematic structures that exist within his/her personality. Dreams are structures that can be redefined and recalled. During the dream, concurrent and harmonious thoughts with the current life style are separated and reinterpreted. These reinterpretations are in fact a way of solving one's problems. Adler states that the current and future-oriented aspects of experiences and conflicts that could not be overcome in the past are tried to be solved by dreams. Yet, the client is not aware of these thoughts of him/her (Oberst and Steward, 2003). The materials obtained from the content of dreams give much information about the client without spending too much time and energy (Carlson \& Slavik, 1997, p. 97) because they the reflections the client's current interests and mental state. That is, they are short-term solutions. Clients can learn recognizing and observing their own internal dynamics by investigating their dreams. Children attach great importance to their dreams. In contrast to what is claimed by Freud, there are no universal or fixed symbols. Symbols are specific to 
people. Dreams cannot be understood without knowing their owner (Mosak, 1997, p. 37; Geçtan, 1981; Carlson \& Slavik, 1997, p. 97). For this reason, in this session the group members were asked to tell the dreams that had profoundly affected them and then they were asked to interpret them and the other group members were asked to interpret them, too.

\section{$6^{\text {th }}$ Session: Secret Drawing}

Secrets are experiences which the person is ashamed of or regrets. The sharing of one's own private secret feelings in a safe environment reduces emotional pressure (Tuzcuoğlu, 1992). In this session, the group members were asked to express through drawing how their thoughts and secrets which they cannot disclose, which they feel guilty of and which compel their minds make themselves feel through the paper and pastels or watercolors given to them. For the group members not to regret later, they were not forced to explicitly express their secrets and the ones who were willing to express were not prevented. Background music was used during the activity and after the completion of the drawings, the group members who wanted made comments on each other's drawings. At the end of session, group members were asked to interpret their own drawings and thus they were allowed to experience emotional discharge.

$7^{\text {th }}$ Session: Wise Man

In this session, it was aimed to develop problem solving, independent and solution-oriented thinking skills of the group members. In the session, all the group members were asked to think about their problems they hadn't solved and made them concerned in their lives. The group members were then divided into two groups and one was the wise man of the other. The wise man was assigned the responsibility of finding solution to the problem of the other. Then the roles were exchanged. The other group members were also asked to think about alternative solutions to the discussed problems. This was repeated for all the pairs and the session was ended.

$8^{\text {th }}$ Session: Aliens Kidnapped

It is an activity to identify coping strategies for the problems to be encountered and to create awareness. The activity starts with the narration of a story. The content of the story is as follows: "You are lying in your bed relaxed after you have finished your routine works at any time in any day and then you have slept. While you are sleeping, you have been kidnapped by aliens. When you open your eyes, you have found yourself in a completely strange place. In this strange place there are a lot of people like you but you haven't met any of them before in your life and it is not possible to communicate with them. There are creatures you have never seen before and these creatures want you to obey some rules. What would you do in such a situation?" This story was given to the group members. Then, they were given some time to think and organize their thoughts. The most common behavior patterns used by the group members in their daily life and the related emotions they felt were discussed.

At the end of the process, they discussed the coping strategies they used against this situation, how frequently they used these strategies in their daily life and whether these coping strategies worked or not. Those having different viewpoints from the others were given the opportunity to talk. Then, the session was ended.

\section{$9^{\text {th }}$ Session: The Last 2 Hours of Your Life}

Many individuals continuously put off what they want to do and put aside the most important moments and thus they reduce their life satisfaction. One of the important causes of unhappiness is that a person cannot really do what he/she wants or, in other words, cannot actualize himself/herself. Many people find the power and courage to perform what they want to do when they remember the existence of death. Therefore, the group members were asked "If today were the last day of your life, would you like to do the things that you normally do?". The group members shared their opinions in relation to this question. The session continued with the activity "letter to my friend".

Letter to my friend: The group members wrote unanimous letters to each other and expressed their opinions about how they perceive the group member to whom the letter was written. In this session, they expressed what they like in the other person, what they are mistaken about the other person and what aspects they think the other person needs to develop. All the sessions were reviewed and the positive and negative sides of group works were discussed. Then the group work was ended after the group members had shared positive feelings and thoughts about each other. 


\section{Findings}

Table 1. The Results of the Single Sample Shapiro-Wilk Test Conducted to Test the Normality of the Distribution of the Johari Window and Subjective Well-Being Scores

\begin{tabular}{|c|c|c|c|c|c|c|c|}
\hline Values & & Feedback Pre-test & $\begin{array}{l}\text { Being Open } \\
\text { Pre-test }\end{array}$ & $\begin{array}{l}\text { Feedback } \\
\text { Post-test }\end{array}$ & $\begin{array}{l}\text { Being Open } \\
\text { Post-test }\end{array}$ & $\begin{array}{l}\text { Total } \\
\text { subjective } \\
\text { well-being } \\
\text { Pre-test }\end{array}$ & \begin{tabular}{l}
\multicolumn{1}{c}{ Total } \\
subjective \\
well-being \\
Post-test
\end{tabular} \\
\hline $\mathrm{N}$ & & 12 & 12 & 12 & 12 & 12 & 12 \\
\hline Normal & $\mathrm{X}$ & 34,70 & 31,33 & 36,83 & 32,83 & 378,25 & 386,41 \\
\hline Parameters & SS & 12 & 12 & 12 & 12 & 12 & 12 \\
\hline Shapiro-Wilk Z & &, 375 & ,011 & ,730 & ,109 & 631 &, 251 \\
\hline $\mathrm{p}$ & & $p>.05$ & $\mathrm{p}<.05$ & $\mathrm{p}>.05$ & $p>.05$ & $p>.05$ & $\mathrm{p}>.05$ \\
\hline
\end{tabular}

According to the results of Shapiro-Wilk Test conducted to determine whether the data are suitable for normal distribution, except for the being open pre-test, the distribution was found to be normal in all the dimensions. As a normal distribution was found for the being open post-test and not so much difference was observed between the non-parametric results of the being open pre-test, in the analysis of all the dimensions, the dependent-samples t-test was preferred.

Table 2. The Results of the Dependent Samples T- test Conducted to Determine Whether there is a Significant Difference between the Experimental Group Pre-test and Post-test Mean Scores Taken from the Johari Window Scale and Subjective Well-Being Scale

\begin{tabular}{|c|c|c|c|c|c|c|c|}
\hline & & Measurement & $\mathrm{N}$ & Mean & $S$ & $\mathrm{t}$ & $\mathrm{p}$ \\
\hline \multirow{4}{*}{ : } & \multirow{2}{*}{ Feedback } & Pre-test & 12 & 34,70 & 2,783 & \multirow{2}{*}{$-3,451$} & \multirow{2}{*}{, 005} \\
\hline & & Post-test & 12 & 36,83 & 2,972 & & \\
\hline & \multirow{2}{*}{ Being open } & Pre-test & 12 & 31,33 & 2,579 & \multirow{2}{*}{$-2,675$} & \multirow{2}{*}{, 022} \\
\hline & & Post-test & 12 & 32,83 & 1,466 & & \\
\hline & \multirow{2}{*}{$\begin{array}{l}\text { Positive Relationships with } \\
\text { Others }\end{array}$} & Pre-test & 12 & 66,25 & 9,215 & \multirow{2}{*}{$-3,559$} & \multirow{2}{*}{,004 } \\
\hline & & Post-test & 12 & 71,83 & 12,575 & & \\
\hline & \multirow[t]{2}{*}{ Autonomy } & Pre-test & 12 & 57,50 & 5,823 & \multirow{2}{*}{,611 } & \multirow{2}{*}{, 554} \\
\hline & & Post-test & 12 & 56,66 & 6,866 & & \\
\hline & \multirow[t]{2}{*}{ invironmental Mastery } & Pre-test & 12 & 59,91 & 9,614 & \multirow{2}{*}{$-1,049$} & \multirow{2}{*}{317} \\
\hline & & Post-test & 12 & 61,91 & 9,336 & & \\
\hline \multirow{4}{*}{ 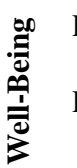 } & \multirow{2}{*}{ Personal Growth } & Pre-test & 12 & 66,08 & 5,915 & \multirow{2}{*}{$-2,006$} & \multirow{2}{*}{,070 } \\
\hline & & Post-test & 12 & 69,50 & 5,823 & & \\
\hline & \multirow{2}{*}{ Purpose in Life } & Pre-test & 12 & 62,33 & 8,116 & \multirow{2}{*}{$-1,638$} & \multirow{2}{*}{130} \\
\hline & & Post-test & 12 & 65,08 & 8,436 & & \\
\hline 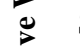 & \multirow[t]{2}{*}{ Self-acceptance } & Pre-test & 12 & 60,66 & 8,381 & \multirow{2}{*}{,- 223} & \multirow{2}{*}{,828 } \\
\hline 苞 & & Post-test & 12 & 61,08 & 7,476 & & \\
\hline$\because \frac{\varrho}{0}$ & Total Subjective Well-Being & Pre-test & 12 & 378,25 & 40,627 & \multirow{2}{*}{,- 966} & \multirow{2}{*}{355} \\
\hline$\overline{\bar{D}}$ & & Post-test & 12 & 386,41 & 38,808 & & \\
\hline
\end{tabular}

As a result of the Dependent Samples T-test conducted to determine whether there is a significant difference between the pre-test and post-test mean scores taken from Johari Window Scale and Subjective Well-Being Scale, it was found that in the "feedback" dimension of Johari Window, the post-test mean score was found to be significantly higher at the significance level of .01 than the per-test mean score and in the "being open" sub-dimension, the post-test mean score was found to be significantly higher at the significance level of .05 than the per-test mean score. Moreover, in the "positive relationships with others" sub-dimension of the subjective well-being scale, the post-test mean score was found to be significantly higher at the significance level of .01 than the per-test mean score. These results indicate that at the end of the 9-session group work, relationships with others improved and the open area that this area is generally easily observable by both the person and the group and includes the information the individual is not hesitant about disclosing.

\section{Results and Discussion}

One of the most important elements that ensure integrity in the establishment of healthy and balanced relations with other members of the society; perhaps the most important one, is the sharing of the information, feelings and needs that the person avoid disclosing with others because on the basis of the secure and intimate relationships lies the sharing of private information with others. Self-disclosure of the individual at appropriate level and at the right time leads to more secure attachments to parents, the opposite sex and friends (Koçak 2002; Çetinkaya \& Akbaba, 2011). Emotions such as the comfort arising from sharing one's problems positively affect the individual's subjective well-being and accordingly 
life satisfaction, an important component of subjective well-being. According to Diener (1994), the subjective well-being also defined as happiness is the evaluation of the extent to which the individual is satisfied with his/her life and the extent to which he/she experiences positive and negative feelings. These evaluations include people's emotional reactions to events, mood and satisfaction with their marriage and business life and their positive or negative judgements about their life satisfaction. People with higher levels of subjective well-being are individuals positively evaluating their own life situations and conditions (Uygur, 2018).

In the related literature, there are explanations and similar study findings that support this finding. Uygur (2018) also remarked that the sense of relaxation brought about for adolescents by sharing their problems would contribute to life satisfaction, and that the increase in self-disclosure behaviors would increase the healthy and close relations in their environment. Demirci \& Şar (2017) showed that self-knowledge and psychological well-being are closely related to each other. Self-knowledge refers to the person's awareness of his experience and standards over time and corresponds to the open area in the Johari window technique. In the study by Behjati, Saeedi, Noorbala, Enjedani and Meybodi (2011), they concluded that a person's level of self-knowledge is positively correlated with both his/her mental and general health. Kahn \& Hessling, (2001), Larson \& Chasting, (1990) concluded that people who hide their unpleasant information experience more stress, their well-being and level of happiness have been adversely affected. In their study investigating the relationships between the subjective and psychological well-being; positive dimensions of mental health, and the styles of the relationships established with other people, Doğan and Sapmaz (2012) found that communicating in a clear, respectful and healthy way contributes to the subjective well-being of the individual. In their study, Gündoğdu and Yavuzer stated that the creation of environments that improve students' subjective well-being, allow the satisfaction of students' basic psychological needs, in which students' personal opinions are appreciated and their sense of belongingness and capacity of effectively interacting with the environment are promoted would enhance the level of well-being (Gündoğdu \&Yavuzer, 2012). Clark (1995) stated that social adjustment could be improved by creating programs that could be implemented within the school, such as collaborative learning, conflict resolution, special education with peers, peers' counseling, communication services and class discussions. In other words, according to research results, the happiness level increases as the person raises his/her awareness of himself / herself.

In the current study, nine-session group work was conducted to expand the "open-area" representing how the individual participating in the group process sees himself/herself, his/her view of the world and how others perceive the individual, to reduce the "unknown area" and to increase the extent to which the individual reveals and his/her well-being level. As a result of the current study, it was observed that the participating university students' open area was expanded and their scores taken from the subjective well-being's sub-dimension of positive relationships with others increased. People's not using effective communication methods leads to conflicts with the environment they are living in. These conflicts are thought to pose a threat to the person's state of well-being and to reduce the capacity of man who is a social entity and creates the meaning of his/her own life through interactions with other members of the society. Luft and Ingham (2014) pointed out that the scope of the open area can be expanded towards the hidden and blind areas when group members actively listen to each other and receive feedback from other group members. Yalom (1992) defined various enhancing elements which he found important for change in group therapies and group works such as inspiring hope, revision of the group members' primary family relationships and dynamics in the group, development of socialization techniques, taking model, interpersonal learning, group commitment, sense of group belongingness and catharsis (Kizıl \& Yalçin, 2015). As a conclusion, in contrast to environments preventing the satisfaction of the basic psychological needs, environments allowing individuals to satisfy their needs were found to be positively affecting well-being and mental health.

When the results of the current research and other research results are evaluated, it can be argued that workshops, seminars or psycho-education programs should be organized at schools by psychological counselors to inform adolescents about behavioral patterns that will facilitate self-disclosure and to seek ways of providing healthy social support for adolescents (Uygur, 2018). The general nature of such programs involves improving the desire to communicate by focusing on the anxiety of helping others, promoting the feeling that someone is valuable and making this feeling internalized. For a society with a high level of mental health and subjective well-being, education and guidance activities can be organized starting from the first years of education, which will improve the self-awareness of children, young people and their families. 


\section{References}

Ağlamaz, T. (2006). Investigation of high school students' aggression scores depending on the self-disclosure behavior, school type, gender, grade level, father and mother's education level and monthly family income. (Unpublished Master's Thesis). Ondokuz Mayıs University Social Sciences Institute. p.35-36.

Armstrong T. R. (2006). Revisiting the Johari Window: Improving Communications Through Self-Disclosure and Feedback, Human Development, 27(2), 10-14.

Arthur, L. (2001). Popular culture and early literacy learning. Contemporary Issues in Early Childhood, 2(3): 295-308. https://doi.org/10.2304/ciec.2001.2.3.3

Ataşalar, J. (1996). University Students' Self-disclosure Behavior depending on their Emphatic Disposition Level, Gender and Age. Unpublished Master's Thesis, Hacettepe University Social Studies Institute.

Balen, G. M. (1999). Social Interest \&Early Recollection In Psychiatrically Hospitalized Adolescents. Unpublished Doctoral Thesis, A Dissertation Submitted To The Faculty Te Adler School Of Professional Psychology, Illinois.USA

Behjati, Z., Saeedi, Z., Noorbala, F., Enjedani, E., \& Meybodi, A. F. (2011). Integrative Self-Knowledge And Mental Health. Procedia - Social And Behavioral Sciences 30, 705-708. https://doi.org/10.1016/j.sbspro.2011.10.137

Brief, A. P., Butcher, A. H., George, J. M., \& Link, K. E. (1993). Integrating Bottom-Up and Top-Down Theories of Subjective Well-Being: The Case of Health. Journal of Personality and Social Psychology, 64(4), 646-653. https://doi.org/10.1037/0022-3514.64.4.646

Burger, J. M. (2006). Personality. İstanbul: Kaknüs Psikoloji.

Büyüköztürk, Ş. (2012). Handbook for Data Analysis in Social Sciences. Ankara: Pegem Akademi.

Carlson, J., \& Slavik, S. (1997). Techniques In Adlerian Psychology. Accelerated Development. Bristol: Taylor \& Francis Group

Çetinkaya, B., \& Akbaba, S. (2011). The relationship between university students' self-disclosure behavior and attachment styles. Black Sea Social Sciences Journal, 3(3), 1-18.

Clarck, A. (2002). Early Recollections: Theory and Practice in Counseling and Psychotherapy. (Paperback). Amazon.co.uk.

Csikszentmihalyi, M. (2005). Science of Happiness. İstanbul: HYB Yayıncılık.

Demirci, İ., \& Şar, A. H. (2017). Investigation of the Relationship between Self-knowledge and Psychological Well-being. Human and Social Sciences Research Journal, 6(5), 2710-2728.

Diener, E. (1994). Assessing subjective well-being: Progress and opportunities. Social Indicators Research, 31, 103-157. https://doi.org/10.1007/BF01207052

Diener, E. (2000). Subjective well-being the science of happiness and a proposal for a national index. American Psychologist, 55(1), 34-43. https://doi.org/10.1037//0003-066X.55.1.34

Doğan, T., \& Sapmaz, F. (2012). Interpersonal Relationship Styles and Subjective Well-being. Turkish Educational Sciences Journal, 10(3), 585-601.

Eryllmaz, A. (2010). The Relationship between the Use of Strategies to Improve Subjective Well-being and Academic Motivation in Adolescents. Clinic Psychiatry, 13:77-84

Fowler, J. C. (2000). Hilsenroth MJ, Handler L, Martin Mayman's Early Memories Technique: Bridging The Gap Between Personality Assessment and Psychotherapy. Journal of Personality Assessment, 75(1), 18-32. https://doi.org/10.1207/S15327752JPA7501_4

Geçtan, E. (1981). Psychoanalysis and Afterwards. İstanbul: Hürriyet Yayınları.

Gündoğdu, R., \& Yavuzer, Y. (2012). Investigation of University Students' Subjective Well-being and Psychological Needs depending on Demographic Variables. Mehmet Akif Ersoy University Education Faculty Journal, 12(23), 115-131.

Kahn, J. H., \& Hessling, R. M. (2001). Measuring the Tendency to Conceal Versus Disclose Psychological Distress. Journal of Social and Clinical Psychology, 20(1), 41-65. https://doi.org/10.1521/jscp.20.1.41.22254

Kılıç, Ö. (2011). Johari Window in Learning Organizations, the Case of Burdur, International Eurasia Social Sciences Journal, 2(5), 1-13. 
Kızıl, Z., \& Yalçın, İ. (2015). A Therapeutic Element in Group Psychological Counseling: Attachment. Mersin Üniversitesieğitimfakültesidergisi, 11(3), 842-850. https://doi.org/10.17860/Efd.26138

Koçak, R. (2002). Aleksitimi: research on theoretical framework treatment approaches. Ankara University Education Faculty Journal, 35(1), 183-2012.

Kopp, R., \& Eckstein, D. (2004). Using Early Memory Metaphors \&Client-Generated Metaphors In Adlerian Therapy, The University Of Texas Pres. Journal Of Individual Psychology, 60 (2), 163-174.

Larson, D. G., \& Chastain, R. L. (1990). Self-Concealment: Conceptualization, Measurement And Health Implications. Journal Of Social And Clinical Psychology, 9(4), 439-455. https://doi.org/10.1521/jscp.1990.9.4.439

Luft, J., \& Ingham, H. (2014). The Model Joe Luft And Harry Ingham: Johari Window. https://richerexperiences.com/wp-content/uploads/2014/02/Johari-Window.pdf

Malhan, S., \& Ersoy, K. (2001). A Study on Communication in Nursing:Johari Window. http://www.Sabem.Saglik.Gov.Tr/Akademik_Metinler/Goto.Aspx?'Id=3668.

Mc.Curdy, J. P. (1986). Early Recollections and Social Interest As Predictor Of Marital Happiness. Unpublished Master's Thesis, Kean College Of New Jersey.

Mosak, H. H. (1984). Adlerian Psychotherapy. (R.J. Corsini \& D. Wedding, Current Psychotherapies Eds.). Ilinois : Peacock Publising Inc.

Nofriza, F. (2017). Development of Training Guide Johari Windows In Improving Student Self Disclosure. Indonesian Journal of School Counseling, 2(1), 41-47. https://doi.org/10.23916/008621923-00-0

Nur Şahin, G. (2011). Comparison of Students' Subjective Well-being and Perceived Social Support Levels. Dokuz Eylül University Educational Sciences Institute Educational Sciences Department Guidance and Psychological Counseling Program. Unpublished Master's Thesis.

Oberst, U. E., \& Stewart. A. E. (2003). Adlerian Psychotherapy: An Advanced Approach To Individual Psychology. New York: Brunner - Routledge Press. Taylor \& Francis Group.

Özen, Ö. (2005). Subjective well-being levels specific to adolescents. Unpublished Master's Thesis, Hacettepe University, Ankara: p.20-25.

Ryff, C. D. (1989). Beyond Ponce de Leon and life satisfaction: New directions in quest of successful aging. International Journal of Behavioral Development, 12, 35-55. https://doi.org/10.1177/016502548901200102

Ryff, C. D. (2014). Psychological Well-Being Revisited: Advances in the Science and Practice of Eudaimonia. Psychother Psychosom, 83, 10-28. https://doi.org/10.1159/000353263

Saygın, Y. (2008). Investigation of University Students' Social Support, Self-esteem, and Subjective Well-being, Selçuk University, Social Sciences Institute, (Unpublished Master's Thesis).

Tuzcuoğlu, S. (1992). Techniques Used in Psychological Counseling. M.Ü. Atatürk Education Faculty, Educational Sciences Journal. 4, 199-213.

Üstündağ, E. (2006). The Effect of the Communication Skills Development Program on the Self-disclosure Behavior of the Security Sciences Faculty Students. Ankara: T.C Ankara University Educational Sciences Institute Educational Sciences Program Psychological Servicers in Education Department, Unpublished Master's Thesis. p:37-43.

Uygur, S. S. (2018). The Role of Self-disclosure and Social Support in Predicting Life Satisfaction. National Education Academy Journal (UEAD), 2(1), 16-33.

Yavuz, Ç. (2006). A Study on the Comparison of the Guidance and Psychological Counseling Students' Subjective Well-being, Psychiatric Symptoms and Some Personality Traits. Unpublished Master's Thesis, İstanbul University Social Sciences Institute.

Yıldız, F. F. (2014). Johari Window and Authentic Leadership: Feedback and Self-disclosure and Self-recognition and Transparency in Relationships. 2. Organizational Behavior Congress, Melikşah University, Kayseri. 313-322.

\section{Copyrights}

Copyright for this article is retained by the author(s), with first publication rights granted to the journal.

This is an open-access article distributed under the terms and conditions of the Creative Commons Attribution license which permits unrestricted use, distribution, and reproduction in any medium, provided the original work is properly cited. 